Critical Sociology 34(2) 169-191

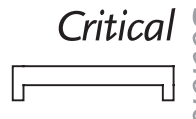

http://crs.sagepub.com

\title{
On the Domestication of American Public Sociology: A Postcolonial Feminist Perspective
}

\author{
Jayati Lal \\ University of Michigan, USA
}

\begin{abstract}
This article engages with the proposal and call for a renewed engagement with civil society by American academic sociology as put forth by Michael Burawoy's 2004 presidential theme for the American Sociological Association. An examination of the history of US academic interdisciplinary scholarship in area-studies programs suggests that the roots of such a knowledge enterprise in the American university are deeply embedded in state and market interests. It is argued that these imbrications of the university in civil society limit the goal of creating a public sociology that can vitalize civil society and foster counter-hegemonic publics. However, greater attention to this history, and to issues of culture, methodology and interdisciplinarity, may assist in the endeavor to foster a critical (counterhegemonic) public sociology.
\end{abstract}

\section{Keywords}

area studies, civil society, feminism, interdisciplinary scholarship, postcolonial critique, public sociology

Our epoch, the epoch of the bourgeoisie, possesses, however, this distinctive feature: it has simplified the class antagonisms. Sociology as a whole is more and more splitting up into two great hostile camps, into two great classes directly facing each other-the professional and the public.

(With apologies to Karl Marx and Frederick Engels, from the Communist Manifesto).

\section{Introduction}

Michael Burawoy's argument in his much celebrated essays, The Critical Turn to Public Sociology (2005a) and Public Sociologies, has as its kernel this message: that politically, society 
and sociology are mirror-like opposites of each other. ${ }^{1}$ When society was more radical during the 1960s, sociologists held on to a conservative ethos and paradigms. As society has moved rightward on the political spectrum, the discipline has moved towards the left. His signal reference points are two referendums against war by the American Sociological Association (hereafter ASA): a resolution against the Vietnam war in 1968, which was opposed by a two thirds majority; and a resolution against the Iraq war in 2003, which passed with a two thirds majority.

In his analysis, this is accounted for by generational shifts: the 1960s sociologists were part of a complacent postwar generation celebratory of the USA, while contemporary sociologists are from a more critical, post-Vietnam generation. Thus, whereas in the 1960s sociology lagged behind progressive movements, 'today, the world is lagging behind sociology' (Burawoy, 2004a: 1604). He describes this historical relation as a 'scissors movement', where 'the political context and the sociological conscience have moved in opposite directions' (Burawoy, 2004a: 1604; 2005a: 324). Today, facing a more reactionary world defined by 'market tyranny and state despotisms' (Burawoy, 2005a: 318), sociology's task is to work on building civil society. Indeed, sociology grew with the birth of civil society and disappeared where civil society died under authoritarian regimes (2005a: 319); civil society and its resilience are thus the 'object and value' of sociology (2005a: 318). Sociology shares the universal humanitarian interest in 'containing if not repelling the terrorist state and the commodification of everything, that ruinous combination we call neoliberalism' (2005a: 319).

In contrast to the academic orientation of radical sociology in the 1970s, Burawoy exhorts us to engage instead in a critical turn to public sociology, turning from interpretation to engagement and from theory to practice, while also being critical of civil society (2005a: 324). In his other articles on public sociology, he articulates a schematic representation of the disciplinary matrix of American sociology as fractured by a fourpart balkanization of the discipline between professional, policy, critical and public sociologies, and argues for their mutual interdependence. In this essay, I engage with this disciplinary schematization of and call to action for a public sociology from the perspective of the histories of US academic area studies programs and the interdisciplinary scholarship that has been produced under their aegis. I argue that these histories are suggestive of the potential limits of the university as a site from which one may promote a public sociology that can vitalize and democratize civil society.

To summarize the argument that follows: first, I argue that in Burawoy's model, the university is detached from civil society, and that the effect of the state and market on the university is consequently elided, as is the presence of civil society in academic sociology and in universities. Drawing on the example of India, I will argue that such a model does not hold true for sociology and the social sciences in postcolonial societies. Furthermore, the history of international (area) studies in the US academy also demonstrates that the USA is no exception to the embeddedness of academic life and knowledge production in civil society. These 'national' histories are not unrelated but, in fact, deeply imbricated. Second, it is unclear how civil society is being (re)constituted in the current era, and hence how we are to distinguish between public sociologies in support of hegemonic or 
counterhegemonic publics. Third, we have no way of understanding how various forms of sociology are linked to their publics, a link that I suggest may be provided by cultural mechanisms, such as a historically constituted (American) academic culture and a public culture of scientism. Fourth, there is a utopic overstatement of the harmonious relations within US sociology that is enabled by a complete silence on the issue of methodologies, which has implications for the growth of public sociology. And finally, there is also a silence about, and hence a negation of, the inter-disciplines that have fostered the development of new publics and are therefore integral to the project of building a public sociology. ${ }^{2}$ Each of these issues, in different ways, produces tendencies towards reformism in academic public sociology, thereby limiting the potential development of counterhegemonic publics.

Although the focus of this commentary is on Burawoy's recent writings on public sociology and civil society, his approach may be taken as symptomatic of an orientation towards civil society that is evident among US left academics more generally. Critical scholars have noted the conjunctural link between the resurgence of interest in civil society and neoliberalism (Comaroff and Comaroff, 2000: 334). While the skeptical view proclaims that we have entered a 'postcivil society' (Hardt, 1995), the Comaroffs are more hopeful that new forms of emancipatory practice will emerge in response to neoliberal capitalism: 'Critical disbelief, in pursuit of a reinvigorated praxis, is the beginning of a solution' (2000: 335). Despite the criticisms that follow, there is no doubt that Burawoy has illuminated the pathway towards this difficult beginning.

\section{The University as Embedded in (and Penetrated by) State and Market}

The history of the American university, and of American sociology along with it, demonstrates the direct structuring and support of academic research projects by state and market interests. This is nowhere clearer than in the growth of area studies during the Cold War. ${ }^{3}$ In fact, as Wallerstein (1997) has argued, area studies were produced by the Cold War as a top-down enterprise via foundations and government agencies. The zeitgeist in the social sciences within the academy during the Cold War was one of support for hegemonic rather than counterhegemonic projects, when there was a reigning 'paradigm of domination' (Simpson, 1998: xx). However, far from national security interests merely following academic social science analyses, 'state and corporate security agencies frequently initiated social science concepts and projects, and the campus followed - not the other way around ... this has been true especially in the emerging, relatively influential interdisciplinary initiatives in the social sciences, such as development studies and area studies' (1998: xiv). Simpson argues that interdisciplinary programs at the 'pace-setting academic institutions' thus often came after state-led initiatives and even emerged to implement them. Furthermore, various funding organizations, such as the Ford Foundation and the Social Science Research Council (SSRC), were part of 'a network of social science funding organizations [which] were subsequently revealed as beards for the CIA - that is, as cover organizations' (Simpson, 1998: xviii). ${ }^{4}$ 
This co-imbrication of the state and university was not limited to the Cold War era in the USA. Cummings (1998) argues that the displacement of disciplinary boundaries in area studies from the early years of the postwar US-Soviet confrontation, to the interest in Pacific Rim studies in the 1970s and the post-Cold War and post-Soviet era in the late 1980s, had a common source, which percolated to the level of disciplinary departments: 'the ultimate force shaping scholarly studies of what used to be called "the non-Western World" is economic and political power, but the most interesting effects of such power were often the least observed, at those local points where (in Foucault's phrase) power becomes “capillary" - as in universities and academic departments' (Cummings, 1998: 159).

Cummings' analysis provides an interesting genealogy of interdisciplinarity in American area studies programs. ${ }^{5} \mathrm{He}$ demonstrates that it was 'state power that shaped area programs' (1998: 163), and he clearly shows the links between the CIA, Ford Foundation, and ACLS/SSRC sponsored academic projects and key personnel during the Cold War (1998: 168-70). Decisions to fund the fields of Chinese and Russian area studies were similarly based on 'investment strategies' and models that fostered and assumed the participation of prominent social scientists in elite universities. Rose's (1998) close reading of the SSRC archive of official papers corroborates the central role of the SSRC in promoting area studies' interdisciplinarity. He notes that it was fostered by funding agencies through the sponsorship of area studies committees, which 'offered an unusually ambitious and productive model for collaboration across the divide between the social sciences and the humanities' (Rose, 1998: 23).

American sociology and the American Sociological Association (hereafter ASA) were part of this process from the very outset. The ASA was one of seven major disciplinary associations that was a founding member of the SSRC when it was constituted in 1923. Other founding professional associations were those of anthropology, economics, history, politics, psychology, and statistics (Rose, 1998: 7-8). ${ }^{6}$ Furthermore, as Rose notes, the SSRC committee on social indicators, where sociologists played a dominant role, was one of the more active arenas of SSRC activity: 'The SSRC was involved in the social indicators movement to an extent that was atypical, although the same could also be said of its role in area studies [...] Indeed, sociology's contributions to the social indicators committee in SSRC were not insignificant, since it was a sociologist, Eleanor Sheldon, who was the Council's president from 1972 to 1978, and who was a key person in this field.' (Rose, 1998: 25)

The role of philanthropic foundations was also crucial in mediating between the interests of the state and the trajectories of intellectual projects and academic research on the third world in the USA and abroad. According to Parmar (2002), the international knowledge network' put in place by American philanthropic organizations such as the Ford and Rockefeller Foundations, and the Carnegie Corporation, produced the hegemony of what he terms 'liberal internationalism', that sought to maintain pro-American perspectives through education. The historic role of American foundations was thus to combat anti-Americanism by selling 'Americanism' (Parmar, 2004). ${ }^{7}$ Given this degree of intervention by the state and agenda setting for national interests, neither the university nor philanthropic foundations that have sponsored research and educational training 
may be placed within a third sector between, or be separated from, state and market (Parmar, 2002: 2).

The corporatization and marketization of American universities today continues this tradition of the academy in the service of state projects. Market needs, in harmony with state-led neoliberalism, facilitate the transformation of campuses in two primary ways. First, there is the commodification of the signs of the university by the market penetration and saturation of new public spheres. This 'logo' centrism brings the visibility and profitability of corporate logos into academic landscapes. One way that this happens is through the corporate sponsorship of athletic programs, and the corporate merchandizing and hence transformation of university logos into brands that accompanies such sponsorship - for example, through the sales of university 'sweat'-shirts manufactured by corporate subcontractors in offshore sweatshops (Klein, 1999). Secondly, there is the commodification (and reification) of particular forms of academic knowledge in the service of market demands. ${ }^{8}$ The globalization of area studies knowledge commodifies area studies to a new end - that of the market's need for 'culturally sensitive' global entrepreneurs who must shed (just) enough ethnocentrism so as not to endanger transnational capitalist projects. A 'global university' rhetoric accompanies the transformation of traditional study abroad programs, which were previously aimed at producing a bourgeois liberal cosmopolitanism in students, into more instrumental, short term (3-4-week, two-credit) courses that transmit a 'global experience' while democratizing the experience to working class kids who may seek to become part of the global managerial class. The 'academic national security complex' (Simpson, 1998: xx) has morphed into the Corporate Global University.

The recent reorganization of area studies into comparative global studies focusing on interregional themes (such as 'the rule of law', 'human rights', and 'democracy'), again led by foundations such as the SSRC, illustrates the ways in which the 'production of academic knowledge has generally followed changes in world power and world markets rather than the other way around' (Simpson, 1998: xxvi). ' Similarly, Cummings (1998: 182) shows how, following the post-Soviet order in the era of 1990 s globalization, 'power and money had found their subject first, and shaped fields of inquiry accordingly'. For Cummings, the recent restructuring of the SSRC, which resulted in the shift from funding area-specific projects towards comparative projects, is a signal of how area studies knowledge is being adapted to and modeled on the needs and operations of the transnational corporation (TNC). As TNCs abandon national corporate offices in favor of functionally divided global offices, the need for a multicultural, multiethnic workforce - for transnational rather than national citizens - is being met by the production of 'global knowledge' in the post-area studies paradigm: 'SSRC is merely following Coca-Cola's lead by making the USA just another subsidiary, just another "area committee"' (Cummings, 1998: 180). ${ }^{10}$

Area studies provides but one venue through which one may track the production of academic knowledge and credentials in the service of the state and the market. ${ }^{11}$ And area studies was an important site where multiple social science disciplines converged to produce knowledge in the service of state power. Arguably, what we see in both periods - during and 
after the Cold War - is not so much a shift from state to market control, but rather, a shift in America's international interests from prioritizing issues of national security to market penetration in the global arena (to the extent that these may be separated in US foreign policy). Yet this conception - of a shift from national control during the Cold War era to one of market control free from state interference in the post-Cold War era - dominates, ironically reiterating the neoliberal philosophy regarding free markets. In his otherwise illuminating study of the transformation of the American academy, Bill Readings also iterates this neoliberal view of the academy as having moved out from being under state control to being 'relatively independent' after the Cold War: He describes the shift in how the American university has been subject/ed to state and market influences during these periods as follows:

The link between the University and the nation-state no longer holds in the era of globalization. The University thus shifts from being an ideological apparatus of the nation state to being a relatively independent bureaucratic system. The economics of globalization mean that the University is no longer called upon to train citizen subjects, while the politics of the end of the Cold War mean that the University is no longer called upon to uphold national prestige by producing and legitimating national culture. (Readings, 1996: 14)

It is not just in the historical present, then, that we can say that the university is subject to the influence (if not direct intervention) of the state and market. But this is the manner in which Burawoy discusses the transformations of and in the University: 'Precisely when we are thinking of extending the impact of our teaching to wider publics the university itself is under siege' and 'As state and market encroach upon the university we can no longer regard ourselves as outside history' (Burawoy, 2005b: 523, emphasis added). ${ }^{12}$ I do not deny that the form and degree that this influence has taken in the past decade has shifted to include the commodification of knowledge, the corporate financing of research, and the proletarianization of faculty, among other changes. ${ }^{13}$ My point is merely that this 'encroachment' is not new, that it is not an encroachment into a previously untouched space; but that it is instead a re-articulation of the embeddeness of the university in civil society, of state and market influences and interests in it, and hence too of the seemingly invisible hand of the market that is directed by the state's neoliberal domestic and foreign policies. Storper regards the view that civil society is 'radically opposed to, and distinct from, states, markets and their handmaiden, corporate power' as a peculiarly North American perspective and as a form of American exceptionalism. Not only is such a position less tenable for other countries with statist economies and societies, but the market saturation and commercialization of social life in the US also calls into question such a separation (Storper, 1998: 244). In other words, in actually existing civil societies, there are only degrees of freedom of civil society from state and market. And, as Storper goes on to note, if this notion of rigid separations is ... imported to places where those separations do not exist, empowerment advocates would unwittingly cooperate in a project of de-statization, a curious project for progressives' (1998: 244). 


\section{Distinguishing between Hegemonic and Counterhegemonic Publics}

Civil society can be the arm of authoritarian and fascist regimes just as easily as it can defend humanity against dictatorship ... civil society is the collaborative arm of all states, to which it is connected by a thousand threads, reproducing consent to capitalism ... Civil society originates its own forms of domination - racial divides, scattered hegemonies of gender, sexuality, capillary powers ... (Burawoy, 2005a: 324).

Civil society is fraught with divisions, and the location of the university within civil society suggests that these divisions permeate the university as well. There are thus multiple public sociologies that can be pursued; indeed, Burawoy suggests that 'we need to pluralize and democratize the very notion of public sociology - hence the idea of public sociologies' (Burawoy et al., 2004: 127). Yet, while critical sociology needs 'to develop normative and institutional criteria for progressive intervention' in civil society (Burawoy, 2005a: 324), we are given no guidelines as to what these might be. ${ }^{14}$ 'As sociologists we not only invent new categories, but also give them normative and political valence' and 'when we study social movements, we simultaneously endorse their presence as a public' (2005a: 323). But the list of possible publics that Burawoy suggests we foster (and endorse) includes only 'liberal' subjects: AIDS patients, single women, gays, the poor, delinquents, women with breast cancer, and the incarcerated (2005a: 323). I suggest he sidesteps the difficult political question that his call for a public sociology engenders, and that is: how do we distinguish between hegemonic and counterhegemonic projects in the domain of public sociology? Between progressive and regressive or conservative counterhegemonies? Between living-wage or anti-sweatshop activists, WTO protesters, the religious right, neo-Nazis, and the Columbine School shooters? Which of these groups should be studied and hence endorsed in the academy? How can we be for civil society but only want to promote some publics? How do we choose between the different publics that we study and hence promote? Does he mean to suggest that we should no longer study rapists, the Christian Right, or terrorists? Obviously, that is not the case. But he is caught in a bind - between adjudicating what is and is not in the interests of a progressive public sociology and thereby universalizing a critical progressive ethic on the one hand, and allowing for a pluralist public sociology that teeters towards moral relativism on the other hand. I suspect that it was in the interests of academic freedom, not to mention a wider, deeper reading (professional) public, that he chose the latter. But the ambivalence of this retreat echoes throughout his writing: critical sociology should be concerned with promoting public sociologies of a 'special kind,' (2005a: 314, emphasis added); critical sociology serves as the conscience of professional sociology (2004a: 1609, emphasis added); and finally, public sociology, 'to have a progressive impact ... will have to hold itself continuously accountable to a vision of democratic socialism' (2005a: 325).

Ellen Wood (1990) suggests that such a 'political retreat' among the champions of civil society on the left stems from the limits of working from civil society in capitalism, which retains its bourgeois nature by merely privatizing the previously extensive and coercive 
states' public power. ${ }^{15}$ In this context, it is interesting to note that the term civil society is being revived in sociology (as among the left at large) at a time when there is exhaustion around the term in activist circles in the global south, due, in part, to the proliferation of civil society and non-governmental organizations (Storper, 1998). We thus need to understand the specificity of civil society in the current moment, which may assist us in addressing Burawoy's dilemma: should sociology seek to promote publics on the left and the right? Is studying a group the same as endorsing it when its politics are not in concert with the researchers'? Cox (1999) provides an excellent analysis of how we might begin to theorize the effects of neoliberalism beyond mere demographic descriptions of civil society (its volume, birth, and death, or its pendulum-like swinging between highs and lows), to a qualitative and comparative-historical understanding of the changing content of civil society. ${ }^{16}$ This enhances our ability to engage in a public sociology that is truly democratic, for he enables us to see that there are political choices to be made and battles to be fought among various 'counterhegemonic' publics.

Cox (1999) theorizes that the expansion of civil society organizations (CSOs) has occurred as a response to globalization; that these organizations have emerged in the space left by the withdrawal of the neoliberal state. ${ }^{17}$ Furthermore, he notes that this 'gap between the retreat of the state and the still small development of civil society' (1999: 13), attracts forms of 'exclusionary populism' such as extreme right wing movements, or xenophobic racism. There is also an expansion of 'covert activities', such as underground criminal activities that may or may not be state sponsored. Cox's analysis thus provides us with an historically informed analytic that can be used to justify 'moral claims' in support of some but not all publics in civil society, since some of these publics can be traced to the retreat of the state and therefore require strong publics and a participatory civil society to counteract them (1999: 14). His analysis can also usefully amplify Burawoy's (2004b) map of different national configurations of the Disciplinary Matrix, by helping us understand how various configurations of national sociologies link to different historical forms of civil society. ${ }^{18}$ This is but one example of the way in which explicating the specific mechanics of how civil society is being reconstituted by the state in the current era of neoliberalism may assist in the otherwise nebulous project of distinguishing between hegemonic and counterhegemonic publics, or even among counterhegemonic publics, without being dismissed as mere ideologues.

But can the social sciences be divided into neatly bounded and boxed-in types, even if ideal typically? The typology of 'national sociologies' affixes these knowledge systems into compartmentalized analytical boxes that freeze a single moment in history (the present), thereby erasing their coeval co-constitutiveness. One of the key means of consolidating and legitimating systems of subordination and rule was through the use of forms of knowledge as part of the project of domination. What this means is that 'Indian sociology' is of necessity engaged and preoccupied with inherited colonial categories of rule such as 'scheduled castes and tribes' (Ahmed, 1991; Barnes, 1982; Cohn, 1996). ${ }^{19}$ Likewise, the categories of modern Western social science have their roots in global projects of domination and rule that cannot be completely extricated from their origins and travels elsewhere, whether through slavery - as with the category of 'race', or through 
imperialism - as with the category of 'development' (Cooper and Packard, 1997). ${ }^{20}$ The task of decolonizing social science thus may not necessarily or only proceed from advancing a critical public sociology in the US academy. As Dipesh Chakrabarty notes, 'European thought is at once both indispensable and inadequate in helping us think through the experiences of political modernity in non-Western nations, and provincializing Europe becomes the task of exploring how this [European] thought - which is now everybody's heritage and which affects us all - may be renewed from and for the margins.' (2000: 17) Furthermore, decolonizing projects have often worked with rather than against the postcolonial nation, but this development of the social sciences in postcolonial societies 'under the sign of the nation' (Das, 2003: 1) does not determinatively mark it as 'policy' scholarship.

What this means is that from a postcolonial perspective, the notion of an 'indigenous professional sociology' (Burawoy, 2004a: 1614-15) is deeply suspect, and unwittingly reproduces a binary between the provincial local and American-as-universal global. Burawoy's conceptions of a 'transnational sociology' (even if from the global south) and a 'global public sociology' (2004a: 1614-15) thus need more careful elaboration. While he is suggesting that global alliances and exchanges among researchers need to move away from what Appadurai (2001) refers to as 'weak internationalization', where one might implicitly globalize a particular American model of sociology, towards a model of 'strong internationalization', where the research conventions, ethics, models of accountability and judgment regarding knowledge are developed in dialogue across national communities, this move is undercut by his assumptions regarding the separate genealogies of American and other (national) sociologies.

\section{Linking Sociology to Its Publics: Cultural Mechanisms}

We also need a better understanding of the cultural mechanisms that link the various forms of academic knowledge that Burawoy has identified - professional expertise, policy statements, critical tracts, and public sociologies - to our publics, and even to our first public, students - whom Abowitz (2000: 382) terms 'educational publics'. It is not sufficient to note that students are a captive audience, and that they are thus subjected to these forms of knowledge in our classrooms, because some forms of knowledge hold greater appeal to students, while others are actively resisted. There is an odd disjuncture between the current popularity of 'reality TV,' 'celebrity' experts, and talk show hosts, alongside a general belief in 'scientism', commonly understood as statistical (and hence objective) knowledge in popular American culture. Dominant cultures of knowledge (such as scientism and positivism) extend beyond their immediate producers, consumers, and promulgators in the academy, to gain a wide purchase in society at large. How else do I explain the curious apathy and skepticism of my undergraduate sociology students when reading Barbara Ehrenriech's Nickel and Dimed (2001) for a course on social inequality? These students, who were more engaged and disturbed by FAIR's (Fairness and Accuracy in Reporting) 'survey data' impugning the so-called 'liberal bias' of the 
mainstream media, dismissed Ehrenreich's powerful first-person, journalistic account of low-wage work in the service economy as proof of her left-leaning 'bias'. ${ }^{21}$ While they did not consider it a distortion of reality, they were apt to read Ehrenreich as presenting a partial reality which therefore did not need to be read as a general description of trends for the American workforce. But they had a much harder time dismissing the 'objective' numerical survey data on the media when it did not accord with their worldviews.

Professional and public sociologists have 'thick' or deep publics in their immediate academic audiences - from their peers to their students - and they are also able to reach deeper into lay publics because of a generalized belief in positivism and the objectivity of scientific facts, especially when these are presented in numbers (Hacking, 1992; Porter, 1995). What I suggest is lacking in Burawoy's analysis, then, is a conception of culture which would enable this linking of specific forms of academic knowledge to cultural beliefs in contemporary America. The specification of such linking mechanisms is necessary in order to understand the resilience of hegemonic worldviews and the deep-seated resistance to counterhegemonic views, or when and how the latter may be taken up in civil society. The mass appeal of scientism and the public trust in 'expert' knowledge are both produced and maintained by the 'professionalism' of academia, as well as by the state's legitimation of positivist social science through its sponsorship of and clientist relation with policy research.

Burawoy's account of professional sociology's detachment focuses on historical effects, such as the generational differences between structural functionalists of the 1950s and 1960 s, who reigned while social unrest and upheaval was greatest, to the generation of critical sociologists who came of age during the 1960s and transformed the discipline in the 1970s. Aside from a 'recalcitrant generation' he notes there are also 'inbuilt tendencies of professions' that have produced these effects (Burawoy, 2005a: 323). But this formulation of detachment as an inherent, and hence unchanging, tendency of professions does not explain the rise of detached professionalism in the discipline in the last two decades. It is possible that there were other more enduring and less visible effects of the Cold War era than were sketched out in the previous Section, and that this period also left its imprint on the professional culture of the US academy at large. James Petras suggests that a hegemonic organizational culture was set in place during a time of state hegemony and control over academics in the Cold War era, a culture that ends up having an enduring structure that he traces into the present. If this is the case, then it may provide an explanation for Burawoy's largely descriptive historical account of sociology's professional ethos.

The CIA's cultural campaigns created the prototype for today's seemingly apolitical intellectuals, academics, and artists who are divorced from popular struggles and whose worth rises with their distance from the working classes and their proximity to prestigious foundations. The CIA role model of the successful professional is the ideological gatekeeper, excluding critical intellectuals who write about class struggle, class exploitation and US imperialism - 'ideological' not 'objective' categories, or so they are told. (Petras, 1999) 


\section{For a Harmonious Sociology, Silence on Methodology}

Burawoy's call for a public sociology is built on a double utopia: not only does it envision a bold new focus on practice for American sociology that goes against the current appeal of abstraction in the professional ethos of the discipline, but it also portrays practitioners of these two sociologies as existing in a normatively harmonious, interdependent coexistence. I would like to suggest that this vision of a harmonious future is enabled only by downplaying significant methodological differences in the discipline. ${ }^{22}$

'In our normative model, the interdependencies among the four species of sociology are symmetrical and harmonious. In reality they are more likely to be hierarchical and antagonistic' (Burawoy, 2004b: 12). He reminds us again that this is a 'normative model of reciprocal interdependence' (2004a: 1611). And although it is possible to have individual cellular 'pathologies' (Burawoy, 2004a: 1607), 'There will always be a tension, a symbiotic opposition if you will, between professional and public sociology that critical sociology will have to navigate.' (Burawoy, 2005a: 323-4, emphasis added). ${ }^{23}$ Burawoy's distinction between the realms of the normative and the real in distinguishing (ideal typical) harmonious and (actual) antagonistic relations between these sociologies does not adequately take account of the significant epistemological differences that constitute them. Furthermore, this extensive reliance on the anachronistic language of structural functionalism by one of American sociology's leading critical sociologists is striking, which leads one to question what 'role' it plays in these manifestos. This silence on methodological differences is all the more puzzling given Burawoy's significant contributions to the discipline in the area of ethnography - both in terms of debates on methodology as well as empirical ethnographic work on labor in a variety of contexts. My conclusion is that this is Burawoy's version of 'strategic essentialism'. In other words, in order to promote his practical, political agenda of getting public sociology some legitimacy in the discipline, he has silenced himself on the issue of methodological differences and stressed our common sociological humanity across our respective cellular sub-disciplinary boundaries.

While I agree with Burawoy that 'without professional sociology there can be no other sociology' (Burawoy et al., 2004a: 105), I tend to see the relationship between professional and other sociologies as more conflictual and power laden than interdependent, even in a normative model. In other words, these models of knowledge are theoretically and epistemologically opposed and have historically been hierarchically related. If we consider the chart on 'The Division of Sociological Labor' (Burawoy, 2004a: 1607), it becomes evident that the descriptors for professional and critical sociology (theoreti$\mathrm{cal} /$ empirical knowledge legitimated through scientific norms, and foundational knowledge legitimated by a moral vision respectively) could easily be substituted by the terms 'positivism' and 'postpositivism' or 'interpretive'. Of course these would only be ideal typical descriptors for the sociologies in each camp, and any individual sociologist would likely combine aspects of both in her sociological practice and research and over the course of her career.

Perhaps more importantly for the purposes of Burawoy's political project, there are significant differences in the methodological 'tendencies' of the two forms of sociology that 
are geared towards non-academic publics: policy sociology is much more quantitative, it is often abstractly generated through surveys or existing data, it seeks generalizations, and is couched in technospeak. Public sociology is more likely to be qualitative, generated though close and perhaps extensive contact with research subjects, seeks to understand particular situations and processes within them, while aiming to speak to a lay audience in relatively jargon free language (see also Burawoy, 2004a: 1611). Not to mention the fact that it may be conducted in collaboration with the public that it is promoting, producing, and disseminating research in a participatory mode. Of course there are some qualitative policy researchers and corporate ethnographic sociologists, just as quantitative research can be very useful to particular publics. ${ }^{24}$ But when sociology 'speaks to power', it is more likely to be in the language of positivist research, although 'speaking truth to power' may involve in-depth portraits and rich contextual details of the particular (though not necessarily micro) case, and hence an interpretive, hermeneutic language. ${ }^{25}$

'In constituting a history of the discipline one danger is to introduce a false homogenization, a history written from the standpoint of the privileged.' (Burawoy, 2004a: 1613) Indeed. One is led to wonder if sociology at the top is more harmonious, and sociology at the bottom, more fractious. Burawoy does note divisions among departments located at elite private universities, state universities, liberal arts colleges, and community colleges: 'I have found public sociology to be both more widely practiced and more highly valued in state colleges than in most elite departments.' (2004a: 1613). Given the power laden binary of professional expert: public sociologist, it is precisely this schism that can reproduce inequalities between elite and state colleges, while limiting the prestige of public sociology.

\section{On Interdisciplinarity: The 'Constitutive Outside' of Public Sociology}

When reading Burawoy's many published statements on public sociology, I am continually struck by the question, 'but why a public sociology?' I realize that as a critical sociologist, Burawoy's concern is to critique his own discipline. Moreover, ASA presidential themes are not unimportant - they often mark turning points in the re-visioning of the discipline, albeit in a lagged manner. What the call for a 'public sociology' signifies at this moment, then, is a rethinking of the discipline and its relation to the wider public - to society - which we address as our disciplinary object. It also suggests a move that acknowledges the role that we play as sociological subjects in society. Hence, it marks a public acknowledgement (in the declared ASA presidential theme) of the necessary melding of the dualism between the object and the subject of the discipline. This has long been the goal of feminist scholarship: to locate the subject and object of knowledge on the same epistemic plane. ${ }^{26}$

But Burawoy wants to carve out a special role for sociology. This is sketched out by a comparative disciplinary division of labor whereby political science, economics, and sociology all have their respective disciplinary objects and values - the state, markets, and society respectively (Burawoy, 2005a: 318; 2005b: 519). This sounds alarmingly like 
'bourgeois' social science and very little like a materialist political economy approach, which would insist instead on their unity! Burawoy's disciplinary division of labor naturalizes a traditional conception of the social sciences and ignores the productive dialogues across the disciplines that have occurred in the past decades. This 'proprietary' disciplinary vision for sociology in the making of public scholarship enacts an erasure of the intellectual exchange and dialogue that has occurred in the past decades between sociology and disciplines such as anthropology, history, english, comparative literature, as well as in interdisciplinary fields such as area studies, race and ethnic studies and gender studies, which have also been fundamentally concerned with public intellectuals' engagement with and critique of society. It also relinquishes the disciplinary objects of language and culture that these disciplines share in common with the social sciences in the making of critical public scholarship. But language and culture are both inextricable from and essential to the functioning of states, markets, and society. They are also critically important to communicative action and rational discourse in the public sphere and in the production of civil society (Habermas, 1989[1962]).

This partitioning of the social sciences in terms of their distinct disciplinary objects is mirrored in Burawoy's balkanization of civil society from private-domestic, market and state influences, and of the university from this triumvirate. But the recognition that civil society is a porous sphere, steeped in market and state influences, is necessary to developing effective counterpublics in 'actually existing democracies' (Fraser, 1998). In the interest of developing strong, valid public research projects and scholarship, instead of compartmentalizing the disciplines, interdisciplinary conversations across the social sciences and humanities and across national boundaries should be actively encouraged.

Burawoy recognizes the established precedents of public scholarship in other fields and in other national contexts, just as he acknowledges that disciplines are 'internally heterogeneous' and not 'watertight compartments' (2005a: 318). 'Public sociology has been the transmission belt of the civil rights and women's movements that have transformed professional sociology' (2004a: 1611). And on feminism and post-structuralism: 'A flourishing professional sociology always has to find space for such critical engagement to facilitate open discussion of what we are up to.' (2004a: 1609) It is therefore all the more ironic that Burawoy wants to build a case for a sociology of civil society, when feminism, area and ethnic studies, and anthropology have been at the forefront of framing and engaging their publics for quite a while. ${ }^{27}$ It is in this sense that I am arguing that interdisciplinarity is actually the constitutive outside of a new public sociology that enables this manifesto, just as sociology's much older antecedents do.

In other words, if the impulses that liberate sociology from its professional anxieties regarding its status as a science, thereby freeing sociologists to take on the role of public sociologist, are coming from its interdisciplinary engagements with feminism, postcolonial theory, global history and the anthropology of the third world, what are the investments in the call for a public sociology now? Why erase the constitutive outside of this moment and movement in sociology? Which is a more important goal in fostering a participatory democratic global civil society: Is it to 'speak to' the center of sociology - its professional base? Or is it to 'speak for' the silent (or silenced) public with the best possible 
speech in the most legible registers that one can muster? What is lost in these erasures of the multiple antecedents to the current moment in sociology? It seems anachronistic for Burawoy to turn insistently inward, to argue for the importance and role of the discipline, for intra-disciplinary dialogue across significant political, methodological, and substantive chasms, and to ignore other more natural affinities between narratively inclined sociologists and humanists, or ethnographically inclined sociologists and anthropologists, who are already engaged in cross-disciplinary conversations.

In a brilliant analysis of the history of historical sociology, Craig Calhoun (1996) argued that the original radical impulse of this 'movement' was domesticated when key historical sociologists sought to gain disciplinary legitimacy at a time when quantitative empiricism reigned supreme. They did this by arguing for a historical sociology on methodological grounds rather than emphasizing the discipline's substantive need for history, or 'the need for theory to be intrinsically historical' (1996: 309), which led to the domestication of the movement within the discipline. Let us not repeat that history in delineating critical sociology's relationship to the discipline at large and to professional sociology in particular. Burawoy's call for a public sociology comes on the heels of a vibrant interdisciplinary movement in the discipline and with the multiple publics that it engages. In seeking to unveil the mystification of the invisible hand of the market by revealing the links between politics, the state, and government in the 'free' market, a Marxist approach would refuse the bourgeois separation of state, economy, and society in analyzing capitalism, while also being methodologically more heterodox. Drawing on this tradition, critical sociology is well equipped to foster and vitalize a radical public sociology. If we domesticate public sociology by tying it to its professional disciplinary roots and to its academic base, we reorient this potential towards reformist social agendas instead.

\section{Conclusions}

While I am sympathetic to Burawoy's vision of and work towards a more utopian future, I am arguing for a realist(ic) understanding of the 'limits of the possible' that are a consequence of the disciplinary history of American sociology, of the necessity to take into account the public spheres in 'actually existing (capitalist) democracies', and the entrenched professional cultures in corporate universities so we can feed the optimism of the will and work against a pessimism of the intellect among public sociologists and other organic intellectuals. And some of the ways that critical sociologists can nurture public sociology are to provincialize and historicize American public sociology, to highlight the fertile conversations that have happened at the borders of the discipline that challenged reigning disciplinary theories and methods, and to make public the histories of academic and disciplinary collusions with hegemonic projects that are aligned with state and/or corporate interests in the USA and abroad.

Revolutionary strategy requires a realpolitik, and there is much to be done in order to attain a 'counterhegemonic alliance of forces on a world scale' (Cox, 1999: 13). It is to 
just such an effort that Burawoy's writings on public sociology are directed. And, for that, we should thank him. Burawoy's 'public sociology' is a clarion call to the discipline. Utilizing the ASA presidential pulpit, he exhorted us to be more cognizant of disciplinary blinders, to unite despite our vast differences around what he identified as a primary goal for sociologists, and to break down the barriers that have kept sociologists removed from the subject of their discipline - the people, and civil society. Burawoy's call for a public sociology is a call for building strategic class alliances within sociology between policy, professional, critical, and public sociologists, and across national boundaries, to support a counterhegemonic project: 'Sociologists of the world unite for a renascent civil society a vibrant participatory, global counter-hegemony!' (Burawoy, 2003: 13).

I also want to highlight the radical nature of his claim - perhaps too radical for some for seeking legitimacy within the hegemonic 'hyper-professionalism' of American sociology for critical, policy-oriented, and public sociologies, and for bringing these into conversation with professional sociology. Yet, as I have endeavored to show in this essay, this call for a public sociology has many silences around issues of methodology that are closely linked to power and privilege in the American academy and in professional sociology. The academy's embeddedness in civil society suggests that 'activist sociology' has had a long and continuing history in the service of both state and market, traced here through the itinerary of area studies scholarship. It is also largely silent on the role of interdisciplinary scholarship in opening up the space for sociology's engagement with its publics, and on how public sociology can better serve its multiple subjugated and subaltern counterpublics through interdisciplinary scholarship in conversation with anthropology, history, area studies, women's studies and race and ethnic studies. Burawoy insistently highlights inward rather than outward-looking disciplinary habits, stressing the importance of public sociology's link to professional sociology. While this may be a good 'legitimating' strategy to gain status and acceptance in the discipline, it may not necessarily lead to sound (or useful) public sociology. But perhaps this merely points to the limits of speaking as a professional sociologist; to the fact that, while ASA presidents make their own history, they do not make it just as they please. Burawoy cannot but make his claims under given circumstances directly encountered and inherited from the past.

An interesting counterpoint to Burawoy's belief in sociology's ability to produce knowledge in the service of counterhegemonic projects and publics is provided by James Petras' revolutionary critique in the online journal, http://www.rebelion.org. Speaking on the war in Iraq, he criticizes American intellectuals for their silence and lack of action. While Burawoy commends sociologists for the high proportion of members who signed an anti-war petition, Petras derides the inaction and lack of solidarity actions on the part of all academics and intellectuals, including public intellectuals, who in his opinion are all aligned with the hegemonic project of the state. In his view, there is no space for a counterpublic of, or produced by, American academics:

And the Western intellectuals? Since the resistance began a year ago ... not a single US intellectual, of the dozens of progressive, critical thinkers ('Not in My Name') has dared to declare their solidarity with the anti-colonial struggle. ... The Western intellectuals are 
a problem.... The paralysis of the US leftist intellectuals, their inability to express solidarity with the Iraqi resistance is a disease which afflicts all 'leftist' intellectuals in the colonial countries. They are fearful of the problem (the colonial war) and fearful of the resolution (national liberation). In the end, the comforts and freedoms they enjoy, the university applause and adulation they receive in the colonial motherland weighs more heavily than the mental costs of a straightforward declaration of support for the revolutionary liberation movements. ... It is not difficult to understand the absence of solidarity with liberation movements among the progressive intellectuals in the imperial countries: they too have been colonized, mentally and materially (Petras, 2004). ${ }^{28}$

It is certainly the case that Petras, who recently retired from his university position at SUNY, Binghamton, speaks more freely (and polemically!) on a weblog forum that functions outside academic strictures and disciplinary constraints. Although Petras' pessimism about the cooptation of US academics is not entirely misplaced, it is also a structurally overdetermined view that lumps together all academics as class-in-themselves by mere virtue of their employment relations. On the other hand, Burawoy's optimism leads him to claim public sociologists as a class-for-themselves, capable of reflexive praxis in the transformation of society into critical publics. I would suggest that the pathway to transforming sociology, and hence to promoting the democratic publics that we seek to endorse, lies somewhere in between a pessimistic dismissal of and a utopic optimism about American sociology and sociologists. While Burawoy may not succeed in changing the hegemonic culture of professionalism, which functions as the modus operandi and the deeply entrenched epistemic belief system in American sociology, at the very least, his interventions on public sociology have succeeded in producing a discursive rupture in the taken-for-granted normative assumption of sociology's professional detachment from present-day issues. That this detachment is peculiarly American, and can survive even at a time of 'war', is further proof of the university's embeddedness in US civil society.

\section{Notes}

1 This essay is partly based on my comments ('Provincializing American Sociology'), as a respondent to Michael Burawoy at the colloquium on 'public sociology' that was held at the Department of Sociology, University of Michigan, November 21 2003. I thank Mark Mizzruci for inviting me to be one of the respondents at that event, and Michael Burawoy and David Fasenfest for inviting me to elaborate further on my verbal comments. I would also like to thank Michael Kennedy and two anonymous reviewers for their comments on an earlier version of this article.

2 My response, as an 'outsider within' sociology (Collins, 1991), is mediated by the two other institutional locations that I inhabit: women's studies and South Asian studies. Historical residues of orientalism are apparent in the persisting institutional organization of knowledge on world areas: 'Middle East studies' and 'Asian languages and cultures' are the only two world areas to (still) have departmental status at the University of Michigan (UM). Southeast Asia, South Asia and the Middle East are also centers under the International Institute which is home for the 'area studies' programs at UM but the simultaneous operation of department status, primarily for the study of languages, is a 
carry-over from the older academic constructions of non-Western area studies. The advertised need (and funding) for Dari (Farsi), Pashtu and Arabic instructors in US area studies programs following the Afghan and Iraq wars revived the overt links between academic area studies and language training for military purposes from the Cold War era.

3 For analysis of the 'Cold War university' and its role in the production of the military-industrialacademic complex, see Chomsky et al. (1997) and Simpson (1998).

$4 \mathrm{I}$ do not mean to suggest that this implicated all social scientists who were funded through these organizations. Clearly, while some scholars were directly involved in research pertaining to state interests, as in the case of Jessie Bernard and Neil Smelser who were involved with project Camelot (Solovey, 2001), other scholars who received such funding have critiqued these institutions and national policy.

5 The logic for interdisciplinarity in area studies arose from the attempt to understand whole cultures. According to Prewitt, SSRC president during 1979-85 and 1995-98, 'At their best area studies investigate an interdependent whole rather than unconnected fragments arbitrarily labeled politics or history or language or economics. This is the celebrated whole-culture approach, difficult to achieve but powerful in its explanatory potential.' (Prewitt, 1982, cited in Rose, 1998: 20). This history of a 'topdown' impulse for interdisciplinarity in area studies is an interesting contrast to its emergence in academic women's studies programs, which has more of a 'bottom-up' history of the transformation of disciplinary knowledge in the emerging field of women's studies that posed a challenge to the disciplinary division of labor into discrete departments within and between the humanities and social sciences. For accounts of the feminist challenge to disciplinary knowledge across the academy, see Farganis (1989), Minnich (1990), Sheridan (1990), and Stanton and Stewart (1995).

6 'Representatives of these associations have sat on governance committees from the time of the Council's founding, and, remarkably, no other disciplinary associations have been added in the intervening years.' (Rose, 1998: 7-8)

7 Parmar defines an 'international knowledge network' as 'a system of coordinated research, results' dissemination and publication, study and often graduate-level teaching, intellectual exchange, and financing, across national boundaries' (Parmar, 2002: 13). His article traces the role of these three foundations in education in Indonesia in the 1940s and 1950s, Latin America in the 1960s and 1970s, and Africa in the 1950s through 1970s. 'Through such networks ... across the world, the foundations exercised intellectual influence by setting the research agenda. They "mobilized bias" by strategically using their vast financial resources to determine which questions were worthy of consideration, how they were to be addressed, the methodologies and paradigms to be employed and which scholars and institutions were to be supported to conduct this research ... the foundations aimed to build policy-relevant research ... that fit western notions of 'development' (2002: 24). For links between these foundations and the Council on Foreign Relations, which has direct influence on US foreign policy, see Parmar $(2004,2005)$. For the role of foundations in the ideology function', and specifically on the role of the Committees on Foreign Relations as a part of the 'ideology network', see Domhoff (1978).

8 For example, Masao Miyoshi (2000) has shown how grants and licensing income shore up the university-industrial complex and further the corporatization of American universities. Arguably, instead of private corporate funds subsidizing academic research, the subcontracting of such research to the university acts as a subsidy to industry by the university, and by the state in the case of land-grant institutions.

9 In 1996, the SSRC ended its joint area committee structure in favor of a program with stronger thematic, cross-regional, and cross-cultural elements (see Rose, 1998: 24). 
10 It is ironic that Coca-Cola's 'provincializing' and particularizing move comes from the imperatives of the local market that potentially restrict the universal appeal of a homogeneous global product. The limits of McDonald's market penetration were made apparent in countries such as France and in India, where it has met with opposition from civil society groups such as the 'slow food' movement in France, and from religious groups in India, where beef is proscribed for Hindus, and pork for Muslims. This forces TNCs to adapt, in a process that marketing agents refer to as ' $\mathrm{g} /$ localizing'. In India, McDonald's responded by creating a 'Maha' (Big) Burger, which uses lamb rather than either beef or pork.

11 The globalization of area studies has transformed race and ethnic studies programs as well. The thematic restructuring of the SSRC in the mid-1990s and the new geographies of globalization have enabled a wider rethinking of area studies (Appadurai, 2000: 14), and have led to a critical turn within diasporic studies by linking them to race and ethnic studies within the university. Thus Kondo (2001: 29) argues that the move towards a critical social science of the Asian diaspora is both a move away from area studies on the one hand and from ethnic (minority) studies on the other hand.

12 I am grateful to Burawoy for sharing an unpublished, forthcoming version of this article with me.

13 On the history of the relation between the university and the state, the university's historic role in the production of 'national culture', and the recent transformation to a market-driven discourse on 'excellence', see Readings, 1996; on the university as 'knowledge factories'; and the proletarianization, casualization, and unionization of university teaching labor, see Aronowitz (2000); Johnson et al. (2003); Nelson (1997a, especially 137-216); and the collected essays in Nelson (1997b); and on the sale of campus marketing rights, named (corporate) professorships, and other forms of outside funding that influence the content of teaching and scholarship, see Soley (1998).

$14 \mathrm{I}$ am less interested here in questions having to do with professionalism - such as those regarding the need to develop criteria of 'good' public sociology and who should evaluate it if it is brought into the purview of professional sociology (cf. Burawoy, 2004a: 1612) - than I am in the question of how we can promote truly counterhegemonic public sociologies. Pursuing the question of which publics one should serve and promote quickly dead-ends in the political starting point from which we articulate our research (i.e. the 'context of discovery'). Since both right-to-life and pro-choice sociologists engage in public sociology, it is less useful to ask which publics we should represent, or to whom we should address our sociology, than it is to examine assumptions about the way in which these publics have been conceived and historically produced. An excellent example of such work would be Faye Ginsberg's ethnography of the abortion debate that explores the making of both the right-to-life and pro-abortion publics in the USA (Ginsberg, 1989). Similar work in India has explored women's participation in the Hindu right (e.g. Sarkar and Butalia, 1995). Such feminist scholarship draws on the notion of a feminist epistemology that begins with bringing the context of discovery, along with the context of justification (the traditional purview of positivist social science), into social science research to develop liberatory knowledge (see Harding, 1986, 1991a, 1991b), which produces 'strong objectivity' (Harding, 1993), in contrast to positivism's weak objectivity which erases the context of justification. It is this erasure that makes positivism no less 'political' than critical social science. At the very least then, the debate cannot be framed as one between a 'value free' and 'value laden' social science, but as one between different political commitments and communities.

15 For Wood, this retreat is the result of the dilution of the 'unequivocal anti-capitalist intent' (1990: 63) in Gramsci's conception of civil society, a 'versatile idea [which] has become an all-purpose catchword for the left, embracing a wide range of emancipatory aspirations, as well - it must be said - as a whole set of excuses for political retreat' (1990: 60). For a critique of the bourgeois concept of 'civil society' among the left, see Goonewardena and Rankin (2004), who argue that the concept of civil 
society serves the Washington Consensus's project of global neoliberalism very well. They suggest that radical politics should redirect its attention from re-building 'civil society' and focus instead on the radical democratization of the state and the economy.

16 Cox outlines the historical and contemporary uses and definitions of 'civil society' and notes that the current usage 'excludes dominant power in the state and corporations from the concept of civil society ... [and] has become the comprehensive term for various ways in which people express collective wills independently of (and often in opposition to) established power, both economic and political.' (1999: 10). This is certainly the way in which Burawoy mobilizes the term, which draws on Gramsci, who 'regarded civil society not only as the realm of hegemony supportive of the capitalist status quo, but also as the realm in which cultural change takes place, in which the counter-hegemony of emancipatory forces can be constituted' (Cox, 1999: 10). For the clearest statement on Burawoy's definition of civil society that I have been able to uncover, see Burawoy (2005b: 519): 'By civil society I mean the constellation of popular associations that group in Europe at the end of the 19th century political parties, trade unions, voluntary organizations, mass education, newspapers.' Interestingly, this Tocquevillian associational definition is at odds with the more Gramscian deployment of the term that is otherwise evident throughout his writings on public sociology.

17 What Cox is alluding to here is the shrinking of the social-welfare functions of the state (education, social security, heath care) at the same time that other (repressive) functions of the state (military, imperial, surveillance) are being strengthened.

18 Burawoy (2004b) has extended the argument that he initially developed as a typology for US sociology to chart sociology in various parts of the world, which he identifies for the following countries: the US (Professional Model), Soviet and post-Soviet Russia, (Policy Model), South Africa (Public Model), and Norway (Welfare Model). In parallel fashion, Cox (1999) develops an analytic model of capitalism in various regions of the world and their accompanying class relations and forms of civil society. While acknowledging the diversity within these regions, he sketches these out as follows: a fragmented civil society among groups representing state and market forces, emancipatory social movements and right wing populist movements in the 'evolved capitalism' of Europe and America; the emergence of a middle-class/worker cross-class alliance in the civil society of Asian capitalist countries; state breakdown and predatory capitalism in post-Soviet Russia, the former Soviet block and parts of Latin America that have suffered the debt crisis, accompanied by a weak civil society; and an incipient civil society that 'has turned its back on the state' (1999: 25) in Africa. Combining these two historical analyses could provide a powerful analytic grid through which we could historicize the relations between civil society and public sociology in various national contexts.

19 Indeed, in the Indian case, the foundations of the current educational system were laid by the British during the colonial period, whose goal was to produce 'Brown Sahibs', or natives who were English by training and Indian by birth. The well known Macaulay minutes provide the most succinct statement of this project (Macaulay, 2001 [1835]): 'We must at present do our best to form a class who may be interpreters between us and the millions whom we govern; a class of persons, Indian in blood and colour, but English in taste, in opinions, in morals, and in intellect.' Parmar (2002) points to the similar effects of (postcolonial) reform-aid projects: the creation of a 'modernizing elite' in Indonesia through Ford Foundation funding (2002: 5-6); and Carnegie's role in creating a cadre of elite blacks while for the most part founding an educational system that reproduced the racial order in Africa between menial and manual labor for blacks, and professional and skilled trades for whites (2002: 9).

20 As Veena Das (2003: 2) notes, the origins of the disciplines in India lie in colonial modernity, thus 'the struggle to define legitimate concerns of social sciences in India today is equally a struggle towards the creation of ... new objects of sociological and anthropological knowledge.' 
21 See Croteau (1998) on the Fairness and Accuracy in Reporting (FAIR) survey of journalists at over 14 news organizations. The survey indicates that most journalists are centrist in their political orientation. Those who are not centrist are more conservative that the public on certain economic issues, and more liberal on social issues.

22 This is not to ignore Burawoy's repeated acknowledgements that in actually existing worlds there are hierarchies of power and domination with subordinate and hegemonic positions. 'I look forward to a unity based on diversity - a unity that incorporates a plurality of perspectives. ... We have to institutionalize these subordinate sociologies within the academy, alongside a hegemonic professional sociology.' (2004a: 1611-12) My point is that this vision of unity slights what are fundamental differences in American sociology that translate methodology into power. He also notes the difficulty of establishing 'stable interdependence without establishing a hierarchy' (2004a: 1611), but assumes that these settle into 'negotiated hegemonies ... [that] attempt to recognize the interests of all, if not in equal measure'.

23 The added emphasis in these quotes is mine.

24 There are obvious exceptions to this broad claim. A classic example is Michael Harrington's The Other America: Poverty and the United States (1984 [1962]). The back cover of the 1969 paperback edition quotes The New York Times describing it as 'One of those rare books that directly influences political action.' Harrington combined statistics, analysis and narratives to present a powerful portrait of poverty. The book had a tremendous impact on the otherwise complacent view of the postwar US economy as the 'Affluent Society', and was widely given credit for having launched the Kennedy and Johnson Administrations' War on Poverty. (I am grateful to an anonymous reviewer for pointing me to this text.)

25 Agger's (2000) book on public sociology provides an interesting contrast to Burawoy in this regard. Agger's intent, like Burawoy's, is 'to foster a public sociology' (2000: 2). Like Burawoy, he too argues that 'Sociology should take the lead in building a democratic public sphere' (2000: 2). However, unlike Burawoy, Agger insistently foregrounds positivism as part of the problem in American sociology that has contributed to the present professional detachment of the discipline. Agger explains how the system of self-referentiality, networks, and closed apprenticeships works to produce structures of enduring inequality that link the kind of sociology one does (postmodern, qualitative, textual or quantitative, mathematical) to one's (class) location in the discipline. He thus seems more willing to locate the production of public sociology as a subjugated practice within academic US sociology.

26 In sharp contrast to professional sociology and its dogged positivism and objectivism, which assume the possibility of sociologists transcending society as subjects while constituting it as their object, Marxist and feminist epistemologies have long acknowledged the falsity of this dualism. For example, Donna Haraway's (1991) feminist materialist notion of 'situated knowledge' builds on the notion of standpoint while rejecting either a pure subjectivist or a particularistic (and hence relativist) epistemology.

27 Buroway extended his initial proposal for a public sociology to the social sciences as a whole, where he addresses more directly the issues of interdisciplinarity and methodology, along with cultural particularism and history (Burawoy, 2005b).

28 For further information on 'Not in Our Name,' or NION, see http://www.nion.us/

\section{References}

Abowitz, K.K. (2000) Civil Society as a Site for Building Educational Publics: Possibilities and Limitations. Educational Studies 31(4): 375-93. 
Agger, B. (2000) Public Sociology: From Social Acts to Literary Acts. Rowman and Littlefield: New York and London.

Ahmed, A. (1991) Between Orientalism and Historicism: Anthropological Knowledge of India. Studies in History 7(1): 133-63.

Appadurai, A. (2001) Grassroots Globalization and the Research Imagination. Public Culture 12(1): $1-19$.

Aronowitz, S. (2000) The Knowledge Factory: Dismantling the Corporate University and Creating True Higher Learning. Beacon Press: Boston.

Barnes, J.A. (1982) Social Science in India: Colonial Import, Indigenous Product, or Universal Truth. H. Fahim (ed.) Indigenous Anthropology in Non-Western Societies: Proceedings of a Burg Wartenstein Symposium, pp. 19-34. Carolina Academic Press: Durham, NC.

Burawoy, M. (2003) South Africanizing U.S. Sociology. From the Left (Newsletter of the Section on Marxist Sociology of the American Sociological Association) 24(3): 1 and 12-13. URL (consulted 22 October 2007): http://www.colorado.edu/Sociology/gimenez/section/From\%20the\%20Left\%20Fall\%202003.pdf

Burawoy, M. (2004a) Public Sociologies: Contradictions, Dilemmas, and Possibilities. Social Forces 82(4): 1603-18.

Burawoy, M. (2004b) 'The World Needs Public Sociology', Sosiologisk Tidsskrift 3, URL (consulted 22 October 2007): http://sociology.berkeley.edu/faculty/burawoy/burawoy_pdf/PS.Norway.pdf

Burawoy, M. (2005a) The Critical Turn to Public Sociology. Critical Sociology 31(3): 313-26.

Burawoy, M. (2005b) Provincializing the Social Sciences. G. Steinmetz (ed.) The Politics of Method in the Human Sciences, pp. 508-25. Duke University Press: Durham, NC.

Burawoy, M., Gamson, W., Ryan, C., Pfohl, S., Vaughan, D., Derber, C. and Schor, J. (2004) Public Sociologies: A Symposium from Boston College. Social Problems 51(1): 103-30.

Calhoun, C. (1996) The Rise and Domestication of Historical Sociology. T.J. McDonald (ed.) The Historic Turn in the Human Sciences, pp. 305-38. Michigan University Press: Ann Arbor, MI.

Chakrabarty, D. (2000) Provincializing Europe: Postcolonial Thought and Historical Difference. Princeton University Press: Princeton and Oxford.

Chomsky, N., Nader, L., Wallerstein, I., Lewontin, R.C. Ohmann, R., Zinn, H., Katznelson, I., Montgomery, D. and Siever, R. (eds) (1997) The Cold War and the University: Toward an Intellectual History of the Postwar Years. New Press: New York.

Cohn, B.S. (1996) Colonialism and Its Forms of Knowledge: The British in India. Princeton University Press: Princeton, NJ.

Collins, P. (1991) Learning from the Outsider Within: The Sociological Significance of Black Feminist Thought. M.M. Fonow and J. Cook (eds) Beyond Methodology: Feminist Scholarship as Lived Research, pp. 35-59. Indiana University Press: Bloomington.

Comaroff, J. and Comaroff, J.L. (2000) Millennial Capitalism: First Thoughts on a Second Coming. Public Culture 12(2): 291-343.

Cooper, F. and Packard, R. (eds) (1997) International Development and the Social Sciences: Essays on the History and Politics of Knowledge. University of California Press: Berkeley.

Cox, R.W. (1999) Civil Society at the Turn of the Millennium: Prospects for an Alternative World Order. Review of International Studies 25(1): 3-28.

Croteau, D. (1998) Examining The 'Liberal Media' Claim: Journalists' Views on Politics, Economic Policy and Media Coverage. URL (consulted 5 September 2007): http://www.fair.org/index.php? page $=2447$

Cummings, B. (1998) Boundary Displacement: Area Studies and International Studies during and after the Cold War. C. Simpson (ed.) Universities and Empire: Money and Politics in the Social Sciences during the Cold War, pp. 159-88. New Press: New York. 
Das, V. (2003) Social Sciences and the Publics. V. Das (ed.) The Oxford India Companion to Sociology and Social Anthropology, pp. 1-29. Oxford University Press: Oxford, New York.

Domhoff, G.W. (1978) The Powers That Be. Vintage Books: New York.

Ehrenreich, B. (2001) Nickel and Dimed: On (Not) Getting by in America. Henry Holt: New York.

Farganis, S. (1989) Feminism and the Reconstruction of Social Science. A. Jaggar and S. Bordo (eds) Gender/Body/Knowledge: Feminist Reconstructions of Being and Knowing, pp. 207-23. Rutgers University Press: New Brunswick.

Fraser, N. (1998) Rethinking the Public Sphere: A Contribution to the Critique of Actually Existing Democracy. C. Calhoun (ed.) Habermas and the Public Sphere, pp. 109-42. MIT Press: Cambridge.

Ginsberg, F. (1989) Contested Lives: The Abortion Debate in an American Community. University of California Press: Berkeley.

Goonewardena, K. and Rankin K.N. (2004) The Desire Called Civil Society: A Contribution to the Critique of a Bourgeois Category. Planning Theory 3(2): 117-49.

Habermas, J. (1989 [1962]) The Structural Transformation of the Public Sphere. MIT Press: Cambridge.

Hacking, I. (1992) Statistical Language, Statistical Truth, and Statistical Reason: The Self Authentication of a Style of Scientific Reasoning. E. McMullin (ed.) The Social Dimensions of Science, pp. 130-57. University of Notre Dame Press: Notre Dame.

Haraway, D. (1991) Situated Knowledges: The Science Question in Feminism and the Privilege of Partial Perspective. D. Haraway Simians, Cyborgs, and Women: The Reinvention of Nature, pp. 183-202. Routledge, Chapman and Hall: New York.

Harding, S. (1986) The Science Question in Feminism. Cornell University Press: Ithaca.

Harding, S. (1991a) Whose Science? Whose Knowledge? Thinking from Women's Lives. Cornell University Press: Ithaca.

Harding, S. (1991b) Reinventing Ourselves as Other: More New Agents of History and Knowledge. S. Harding: Whose Science? Whose Knowledge? Thinking from Women's Lives, pp. 268-95. Cornell University Press: Ithaca.

Harding, S. (1993) Rethinking Standpoint Epistemology: 'What Is Strong Objectivity'? L. Alcoff and E. Potter (eds) Feminist Epistemologies, pp. 49-83. Routledge, Chapman and Hall: New York.

Hardt, M. (1995) The Withering of Civil Society. Social Text 45(14): 27-44.

Harrington, M. (1984 [1962]) The Other America: Poverty and the United States. Holt, Rinehart, and Winston: New York.

Johnson, B., Kavanagh, P. and Mattson, K. (eds) (2003) Steal This University:The Rise of the Corporate University and the Academic Labor Movement. Routledge: New York.

Klein, N. (1999) No Space, No Choice, No Jobs, No Logo: Taking Aim at the Brand Bullies. Picador (St. Martin's Press): New York.

Kondo, D. (2001) (Un)Disciplined Subjects: (De)Colonizing the Academy? K. Chuh and K. Shimakawa (eds) Orientations: Mapping Studies in the Asian Diaspora, pp. 29-40. Duke University Press: Durham, NC.

Macaulay, T. (2001 [1835]) Minutes on Education in India, 1835. A. Burton (ed.) Politics and Empire in Victorian Britain: A Reader, pp. 18-20. Palgrave: New York.

Marx, K. and Engels, F. (1986 [1888]) The Communist Manifesto. Penguin Books: London.

Minnich, E.K. (1990) Transforming Knowledge. Temple University Press: Philadelphia.

Miyoshi, M. (2000) Ivory Tower in Escrow. Boundary 2 27(1): 7-50.

Nelson, C. (1997a) Manifesto of a Tenured Radical. New York University Press: New York and London.

Nelson, C. (ed.) (1997b) Will Teach for Food: Academic Labor in Crisis. University of Minnesota Press: London and Minneapolis.

Parmar, I. (2002) American Foundations and the Development of International Knowledge Networks. Global Networks: A Journal of Transnational Affairs 2(1): 13-30. 
Parmar, I. (2004) Selling Americanism, Combatting Anti-Americanism: The Historical Role of American Foundations. Budapest, Hungary: Center for Policy Studies, Central European Univeristy (Anti-Americanism Working Papers). URL (consulted 5 September 2007): http://www.ceu.hu/ cps/pub/pub_papers_antiamer_parmar.pdf.

Parmar, I. (2005) Catalysing Events, Think Tanks and American Foreign Policy Shifts: A Comparative Analysis of the Impacts of Pearl Harbor 1941 and 11 September 2001. Government and Opposition 40(1): $1-25$.

Petras, J. (1999) The CIA and the Cultural Cold War Revisited. Monthly Review 51(6): 47-56.

Petras, J. (2004) Third World Resistance and Western Intellectual Solidarity. July 4, 2004. URL (consulted 5 September 2007): http://www.rebelion.org

Porter, T.M. (1995) Trust in Numbers: The Pursuit of Objectivity in Science and Public Life. Princeton University Press: Princeton.

Prewitt, K. (1982) Annual Report of the President. Social Science Research Council Annual Report, 1981-82. Social Science Research Council: New York.

Readings, B. (1996) The University in Ruins. Harvard University Press: Cambridge, MA.

Rose, K.W. (1998) A Guide to the Social Science Research Council Archives at the Rockefeller Archive Center. The Rockefeller University/Rockefeller Archive Center: New York.

Sarkar, T. and Butalia, U. (eds) (1995) Women and Right-Wing Movements: Indian Experiences. Zed Books: London and New Jersey.

Sheridan, S. (1990) Feminist Knowledge, Women's Liberation, and Women's Studies. S. Gunew (ed.) Feminist Knowledge: Critique and Construct, pp. 36-58. Routledge: London.

Simpson, C. (ed.) (1998) Universities and Empire: Money and Politics in the Social Sciences during the Cold War. The New Press: New York.

Soley, L. (1998) The New Corporate Yen for Scholarship. C. Simpson (ed.) Universities and Empire: Money and Politics in the Social Sciences during the Cold War, pp. 229-50. New Press: New York.

Solovey, M. (2001) Project Camelot and the 1960s Epistemological Revolution: Rethinking the PoliticsPatronage-Social Science Nexus. Social Studies of Science 31(2): 171-206.

Stanton, D.C. and Stewart, A.J. (1995) Introduction: Remodeling Relations: Women's Studies and the Disciplines. D.C. Stanton and A.J. Stewart (eds) Feminisms in the Academy, pp. 1-18. University of Michigan Press: Ann Arbor.

Storper, M. (1998) Civil Society: Three Ways into a Problem. M. Douglass and J. Friedman (eds) Cities for Citizens: Planning and the Rise of Civil Society in a Global Age, pp. 239-46. Wiley: Chichester.

Wallerstein, I. (1997) The Unintended Consequences of Cold War Area Studies. N. Chomsky et al. (eds) The Cold War and the University: Toward an Intellectual History of the Postwar Years, pp. 195-231. New Press: New York.

Wood, E.M. (1990) The Uses and Abuses of 'Civil Society'. R. Milliband, L. Panitch and J. Saville (eds) The Retreat of the Intellectuals: The Socialist Register, 1990, pp. 60-84. Monthly Review Press: London and New York.

For correspondence: Jayati Lal, 4148 LSA Building, University of Michigan, 500 S. State Street, Ann Arbor, MI, USA, 48109-1382. Email: jlal@umich.edu. 